\title{
Nitrate regulates floral induction in Arabidopsis, acting independently of light, gibberellin and autonomous pathways
}

\author{
Inmaculada Castro Marín • Irene Loef • \\ Linda Bartetzko • Iain Searle · George Coupland • \\ Mark Stitt · Daniel Osuna
}

Received: 27 August 2010/Accepted: 4 November 2010/Published online: 27 November 2010

(C) The Author(s) 2010. This article is published with open access at Springerlink.com

\begin{abstract}
The transition from vegetative growth to reproduction is a major developmental event in plants. To maximise reproductive success, its timing is determined by complex interactions between environmental cues like the photoperiod, temperature and nutrient availability and internal genetic programs. While the photoperiod- and temperature- and gibberellic acid-signalling pathways have been subjected to extensive analysis, little is known about how nutrients regulate floral induction. This is partly because nutrient supply also has large effects on vegetative growth, making it difficult to distinguish primary and secondary influences on flowering. A growth
\end{abstract}

I. Castro Marín and I. Loef contributed equally to the research.

Electronic supplementary material The online version of this article (doi:10.1007/s00425-010-1316-5) contains supplementary material, which is available to authorized users.

I. Castro Marín · L. Bartetzko · M. Stitt · D. Osuna

Max Planck Institute for Molecular Plant Physiology,

Am Mühlenberg 1, 14476 Golm, Germany

I. Loef

Botany Institute, University of Heidelberg, Im Neuenheimer

Feld 360, 69120 Heidelberg, Germany

I. Searle · G. Coupland

Max Planck Institute for Plant Breeding Research,

Carl-von-Linné-Weg 10, 50829 Cologne, Germany

Present Address:

D. Osuna $(\square)$

Dpto. de Fisiología Vegetal, Centro Hispano-Luso de

Investigaciones Agrarias, Facultad de Biología, Universidad de

Salamanca, C/Río Duero 12, 37185 Salamanca, Spain

e-mail: daniel.osuna@usal.es system using glutamine supplementation was established to allow nitrate to be varied without a large effect on amino acid and protein levels, or the rate of growth. Under nitrate-limiting conditions, flowering was more rapid in neutral $(12 / 12)$ or short $(8 / 16)$ day conditions in C24, Col-0 and Laer. Low nitrate still accelerated flowering in late-flowering mutants impaired in the photoperiod, temperature, gibberellic acid and autonomous flowering pathways, in the $\mathrm{fca}$ co-2 gal-3 triple mutant and in the $f t-7$ soc $1-1$ double mutant, showing that nitrate acts downstream of other known floral induction pathways. Several other abiotic stresses did not trigger flowering in $\mathrm{fca}$ co-2 gal-3, suggesting that nitrate is not acting via general stress pathways. Low nitrate did not further accelerate flowering in long days (16/8) or in $35 S:: C O$ lines, and did override the late-flowering phenotype of $35 S:: F L C$ lines. We conclude that low nitrate induces flowering via a novel signalling pathway that acts downstream of, but interacts with, the known floral induction pathways.

Keywords Arabidopsis - Floral induction - Nitrate · CONSTANS $\cdot$ FLC

\begin{tabular}{|c|c|}
\hline Abbre & iations \\
\hline $\mathrm{N}$ & Nitrogen \\
\hline NR & Nitrate reductase \\
\hline GA & Gibberellic acid \\
\hline $\mathrm{CO}$ & CONSTANS \\
\hline FLC & FLOWERING LOCUS C \\
\hline FT & FLOWERING LOCUS T \\
\hline SOC1 & $\begin{array}{l}\text { SUPPRESSOR OF OVEREXPRESSION } \\
\text { CONSTANS } 1\end{array}$ \\
\hline LFY & LEAFY \\
\hline
\end{tabular}




\section{Introduction}

Nitrogen $(\mathrm{N})$ is the most important inorganic nutrient for plant growth (Marschner 1995; Miller et al. 2007). The major source of $\mathrm{N}$ is usually nitrate, with ammonium and amino acids also sometimes making a contribution (Miller et al. 2007). The $\mathrm{N}$ supply affects all levels of plant function, from metabolism through to allocation and development (Marschner 1995; Crawford 1995; Stitt and Krapp 1999; Lea and Azevedo 2006; Zhang et al. 2007; Hirel et al. 2007). At a cellular level, $N$ regulates nitrate and ammonium uptake and reduction, $\mathrm{N}$ and carbon metabolism, secondary metabolism and cellular growth (Scheible et al. 1997a, 2000, 2004; Wang et al. 2000, 2003; Gutiérrez et al. 2007; Vidal and Gutiérrez 2008). N regulates developmental processes like germination (Alboresi et al. 2005), shoot-root allocation (Scheible et al. 1997b; Stitt and Krapp 1999), lateral root growth (Zhang and Forde 1998; Zhang et al. 1999, 2007; Tian et al. 2008), the timing of flowering (Klebs 1913; Dickens and van Staden 1988; Bernier et al. 1993) and senescence (Wang et al. 2000; Vanacker et al. 2006).

Studies with genotypes exhibiting low nitrate reductase (NR) activity have shown that some of the responses to $\mathrm{N}$ are triggered by nitrate. NR-deficient genotypes accumulate high levels of nitrate but contain low levels of amino acids and other $\mathrm{N}$-containing metabolites, low protein and have low rates of growth (Scheible et al. 1997a, b; Wang et al. 2004). Nitrate induces genes required for the uptake and reduction of nitrate, ammonium assimilation, the oxidative pentose pathway, and glycolysis and organic acid metabolism (Crawford 1995; Scheible et al. 1997a, 2000; Wang et al. 2004; Gutiérrez et al. 2007), and represses phenylpropanoid metabolism (Fritz et al. 2006). Nitrate regulates also shoot-root allocation (Scheible et al. 1997b), root architecture (Vidal et al. 2010), and triggers a local stimulation of lateral root growth (Zhang and Forde 1998; Zhang et al. 1999; Tian et al. 2008). The details of the signalling pathway still need to be elucidated. High-affinity nitrate transporters might play a role in sensing nitrate (Little et al. 2005; Remans et al. 2006). Nitrate-dependent induction of IPT3 in the roots leads to increased synthesis and export of cytokinins to the shoot (Sakakibara et al. 1998; Takei et al. 2004). In Arabidopsis plants induced to flower by exposure to a single 22-h-long day, cytokinins increases correlate with the successive steps of the floral transition (Corbesier et al. 2003). Transcript profiling has identified many transcription factors, protein kinases and protein phosphatases that are rapidly induced or repressed by nitrate (Wang et al. 2003; Scheible et al. 2004; Gutiérrez et al. 2007).
Other responses require metabolisation of nitrate, and are presumably triggered by metabolites lying further downstream in $\mathrm{N}$ metabolism, by accompanying changes in other pathways, or by changes in cellular activities that occur when the $\mathrm{N}$ supply increases. For example, downstream signalling regulates large sets of genes involved in cellular growth, including genes encoding components of the protein synthesis apparatus (Wang et al. 2004; Scheible et al. 2004; Gutiérrez et al. 2007). There are probably multiple mechanisms for sensing changes that occur when nitrate is assimilated. In bacteria and fungi the $\mathrm{P}_{\mathrm{II}}$ protein acts as a sensor for 2-oxoglutarate and glutamate, two metabolites at the interface between $\mathrm{N}$ and carbon metabolism. Plants contain putative homologues to the $\mathrm{P}_{\mathrm{II}}$ protein (Hsieh et al. 1998; Smith et al. 2003), which have been shown to bind 2-oxoglutarate (Kamberov et al. 1995; Smith et al. 2003; Moorhead and Smith 2003). Plants also contain a large family of glutamate receptor-like (GLR) genes (Kang and Turano 2003; Filleur et al. 2005; Forde and Lea 2007).

The transition from vegetative growth to flowering represents one of the most important events in the life history of a plant (Koornneef et al. 1998; Simpson et al. 1999; Mouradov et al. 2002). It is regulated by an interplay between environmental and endogenous factors, which communicates when the time of the year and/or the growth conditions are favourable for sexual reproduction and seed maturation. Genetic studies in Arabidopsis have identified several floral induction signalling pathways including the photoperiod, the vernalisation the gibberellic acid (GA) and the autonomous pathways (Fig. 1; Mouradov et al. 2002; Simpson and Dean 2002; Corbesier and Coupland 2006).

The photoperiod pathway integrates inputs from the circadian clock and light receptors, and promotes flowering in long days (Suárez-López et al. 2001; Valverde et al. 2004). CONSTANS (CO) activity leads to expression of FLOWERING LOCUS T (FT; Wigge et al. 2005), which promotes floral initiation. In many accessions, vernalization is a prerequisite for floral induction (Sheldon et al. 2000; Kim et al. 2009) by leading to a decrease of FLOWERING LOCUS C (FLC; Levy and Dean 1998). The GA-signalling pathway promotes flowering (Langridge 1957; Wilson et al. 1992; Cheng et al. 2004), and requires genes for GA synthesis like GAl (Sun et al. 1992) and genes involved in GA-signalling like GAI (Lee et al. 2002). Flowering is also promoted by the so-called autonomous pathway, which includes genes encoding components of RNA processing or histone modification complexes (Simpson and Dean 2002).

These signalling pathways interact to determine the timing of flowering. The photoperiod and GA pathways converge on a common set of floral pathway integrators, including FT (see above), a SUPPRESSOR OF 
Fig. 1 Pathways controlling flowering time in Arabidopsis. Adapted from Corbesier and Coupland (2006)

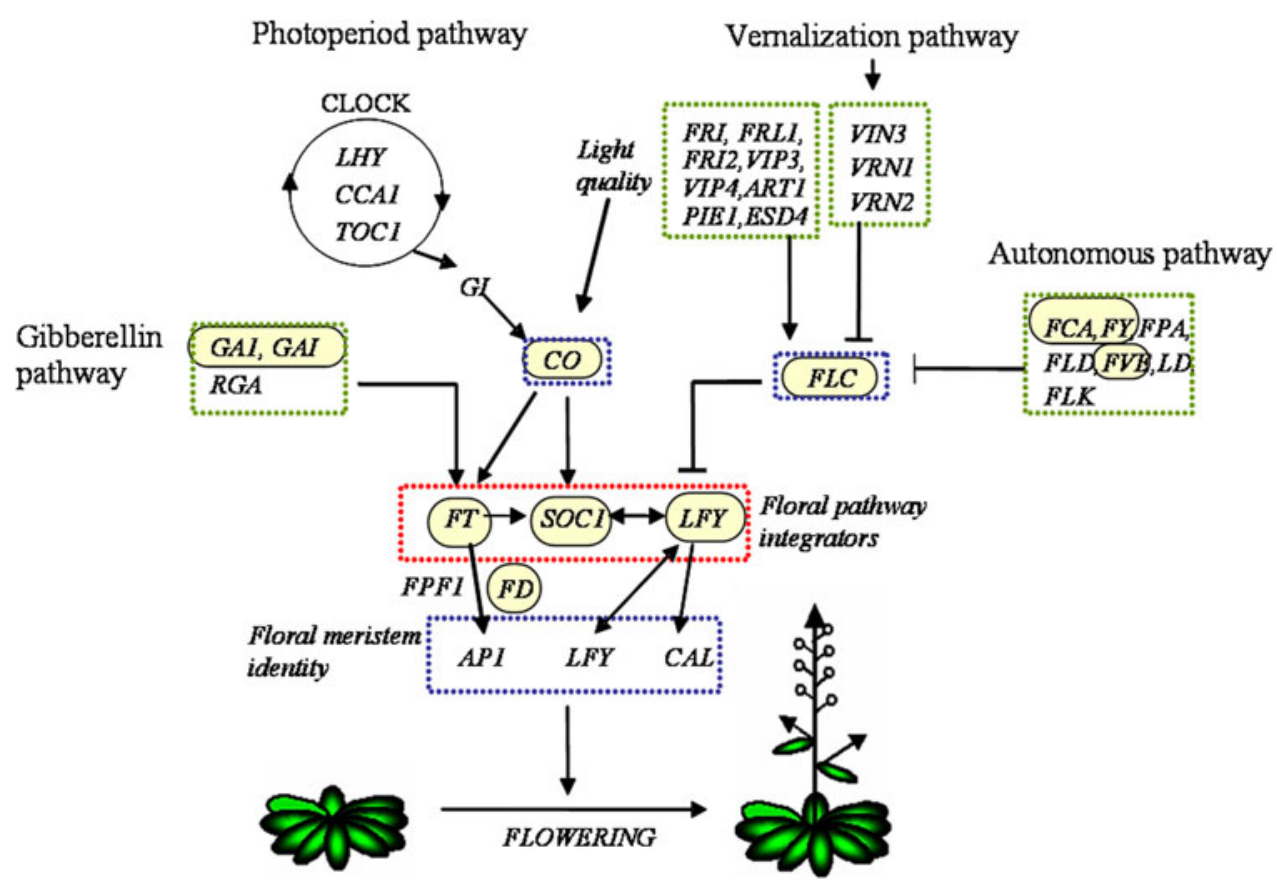

OVEREXPRESSION OF CONSTANS 1 (SOC1; Lee et al. 2000; Samach et al. 2000; Moon et al. 2003) and $L E A F Y$ ( $L F Y$; Blázquez and Weigel 2000). FLC acts by negatively regulating $F T$ and $S O C 1$, and thus, overrides the photoperiod and the GA-signalling pathways. Vernalization and the autonomous pathway act by epigenetic silencing of FLC (Simpson and Dean 2002; Sung and Amasino 2004), allowing promotion of flowering by the photoperiod and GA pathways.

$\mathrm{N}$ has been known for almost a century to modify the timing of flowering (Klebs 1913). Flowering is often delayed by a high $\mathrm{N}$ supply and is accelerated by high rates of photosynthetic $\mathrm{CO}_{2}$ fixation, which are thought to deplete N (reviewed in Bernier et al. 1981; Dickens and van Staden 1988; Bernier et al. 1993). It may promote reproduction and redistribution when the $\mathrm{N}$ supply is low, and allow exploitation of the resources to establish a larger vegetative biomass, and ultimately a larger number of seeds, when there is a more ample supply of $\mathrm{N}$. The influence of $\mathrm{N}$ fertilisation on flowering is also an important factor in agriculture. $\mathrm{N}$ fertilisation has been a powerful tool to increase yield of cultivated plants, but can lead to a delay in flowering or tuberisation (Marschner 1995; Wiltshire and Cobb 1996). More generally, understanding the regulation of the plant $\mathrm{N}$ economy may help to improve $\mathrm{N}$ use efficiency (Hirel et al. 2007).

The mechanism by which the $\mathrm{N}$ supply influences flowering is unknown. The following experiments were carried out to address two questions. First, is the delayed transition to flowering in high $\mathrm{N}$ conditions triggered by changes in nitrate, or is it due to a general change in the level of organic nitrogen metabolites? Second, how does N-signalling interact with other known and genetically characterised floral induction pathways?

\section{Materials and methods}

Plant material

Landsberg erecta (Laer), Columbia (Col-0) and C24 Arabidopsis thaliana accessions, different flowering-time mutants and transgenic plants with modified expression in flowering-time genes in the Laer or Col-0 background were obtained from the Nottingham Arabidopsis Stock Centre. Transgenic lines were generated in George Coupland's group, (Max Plank Institute for Plant Breeding Research, Cologne, Germany).

Plant growth media and conditions

Seedlings were grown on horizontal agar plates under sterile growth conditions. Briefly, seeds were surface sterilized in bleach solution containing 3\% $\mathrm{NaHClO}$ plus $0.005 \%$ (w/v) Tween 20 for $15 \mathrm{~min}$, washed 3 times with sterile distilled water, resuspended in $0.15 \%$ sterile agar, and distributed on agar plates containing nutrient medium with 1,10 or $35 \mathrm{mM}$ nitrate, and $1 \mathrm{mM} \mathrm{MgSO}_{4}, 2.5 \mathrm{mM}$ $\mathrm{KCl}, 3 \mathrm{mM} \mathrm{KH} \mathrm{PO}_{4}, 2 \mathrm{mM} \mathrm{CaCl}$, $4 \mathrm{mM}$ glutamine, $1 \%$ sucrose, $0.021 \mathrm{mM}$ FeEDTA, $0.075 \mathrm{mM} \mathrm{H}_{3} \mathrm{BO}_{3}, 17.5 \mu \mathrm{M}$ $\mathrm{MnSO}_{4}, 1.25 \mu \mathrm{M} \mathrm{ZnSO}, 0.75 \mu \mathrm{M} \mathrm{CuSO}{ }_{4}, 0.5 \mu \mathrm{M} \mathrm{NiCl}_{2}$, $0.375 \mu \mathrm{M} \mathrm{Na}_{2} \mathrm{MoO}_{4}, 25 \mathrm{nM} \mathrm{CoCl}$, and $3 \mathrm{mM} \mathrm{MES}(\mathrm{pH}$ 
5.6). Sucrose and glutamine were filtered and added after autoclaving. Some experiments used 0.5 and $10 \mathrm{mM}$ nitrate without glutamine. Phosphate starvation treatments used a final $\mathrm{KH}_{2} \mathrm{PO}_{4}$ concentration of $200 \mu \mathrm{M}$. The plates were sealed with Leucopore tape (Beiersdorf, Hamburg, Germany), at $4^{\circ} \mathrm{C}$ for $3-5$ days, and transferred to sterile growth chambers, with $20^{\circ} \mathrm{C}$ day/night and $120 \mu \mathrm{mol}$ photons $\mathrm{m}^{-2} \mathrm{~s}^{-1}$ light with a day length as specified in the figure legends. Plants were visually scored each day for floral buds.

To investigate abiotic stresses, wild-type Laer and fcaco2gal-3 were grown on soil. Control plants were grown in a $12 \mathrm{~h} \mathrm{light} / 12 \mathrm{~h}$ dark photoregime (ca. $120 \mu \mathrm{mol} \mathrm{m} \mathrm{m}^{-2} \mathrm{~s}^{-1}$ light), $60 \%$ relative humidity and $20^{\circ} \mathrm{C}$, unless indicated otherwise. The high light treatment was $800 \mu \mathrm{mol} \mathrm{m} \mathrm{m}^{-2} \mathrm{~s}^{-1}$ in a $8 \mathrm{~h} \mathrm{light} / 16 \mathrm{~h}$ dark photoperiod, high temperature was $26^{\circ} \mathrm{C}$ day $/ 22^{\circ} \mathrm{C}$ night in a $12 \mathrm{~h}$ light/ $12 \mathrm{~h}$ dark photoperiod, photochilling was $16^{\circ} \mathrm{C}$ day/night, $800 \mu \mathrm{mol} \mathrm{m}{ }^{-2} \mathrm{~s}^{-1}$ in a $12 \mathrm{~h} \mathrm{light} / 12 \mathrm{~h}$ dark photoregime, and continuous light was with $120 \mu \mathrm{mol} \mathrm{m}^{-2} \mathrm{~s}^{-1}$ light at a temperature of $20^{\circ} \mathrm{C}$.

\section{Determination of metabolites}

The soluble fraction of ethanol extracts was used to measure glucose, fructose, sucrose, nitrate and total amino acids (Fritz et al. 2006), and the residual fraction for protein and starch analysis (Geigenberger et al. 1996; Scheible et al. 1997a).

\section{Results}

Establishment of an experimental system in which nitrate and organic nitrogen can be varied independently of each other

Addition of nitrate to a plant alters the level of nitrate, the levels of downstream metabolites, and the rate of growth. Previous studies used genotypes with low or no NR activity to separate these responses. For studies of flowering, this approach has two disadvantages. First, although low-NR genotypes allow nitrate to be varied independently of downstream events, this is achieved against a background of low levels of N-containing metabolites and slow growth. To study flowering, it would be more appropriate to use a treatment that allows nitrate to be varied in the presence of high organic $\mathrm{N}$, to avoid possible complications due to nonspecific effects of slow growth per se. Second, it would be very tedious to screen the interaction between $\mathrm{N}$ and existing floral induction pathways in this genetic background, because this would require lengthy crossing programs to generate genotypes that are homozygous for multiple mutations or transgenes. For this reason, we explored whether glutamine supplementation can be used as an alternative approach. In this approach, the nitrate concentration is varied, while supplying glutamine as a constitutive source of $\mathrm{N}$. Addition of $4 \mathrm{mM}$ glutamine to Arabidopsis growing on $0.2 \mathrm{mM}$ nitrate restored growth to above that seen on $10 \mathrm{mM}$ nitrate (data not shown). Other amino acids including asparagine, aspartate, glutamate and alanine were less effective (data not shown).

Figure 2 summarizes the response when the Arabidopsis accession $\mathrm{C} 24$ is grown with 1,10 or $35 \mathrm{mM}$ nitrate in the presence of $4 \mathrm{mM}$ glutamine as a constitutive $\mathrm{N}$ source on nutrient agar in weak light in a $12 \mathrm{~h}$ light/12 h dark photoregime. The plants were visually scored each day for the presence of a flower bud. At the time when ca. $30 \%$ of the plants in a given treatment had started to flower, all plants with a flower bud were harvested for destructive analysis. The remaining plants were visually scored for flowering for the remainder of the experiment. Decreased nitrate led to flowering at an earlier time (Fig. 2a), after producing fewer leaves (Fig. 2b) and with a lower shoot fresh weight at the time of flowering (Fig. 2c). Similar results were obtained for Laer (see Supplemental Fig. S1) and Col-0 (see below).

Total plant fresh weight when ca. $30 \%$ of the plants had started to flower was 187,325 and $554 \mathrm{mg}$ for plants growing on 1, 10 and $35 \mathrm{mM}$ nitrate (Fig. 2c, data not shown). This corresponded to day 22, 26 and 30 after germination, respectively. Based on the total plant weight and a seed weight of $0.025 \mathrm{mg}$, and assuming exponential growth over the life cycle of the plant, we estimated an average relative growth rate of about $0.24,0.22$ and 0.21 on 1,10 and $35 \mathrm{mM}$ nitrate, respectively. This provides direct evidence that inclusion of glutamine in the medium largely reverses the inhibition of growth in low nitrate. The shoot/ root ratio typically decreases in low $\mathrm{N}$, because root growth is inhibited less strongly than shoot growth. It is known that this response is regulated by nitrate. This decrease of the shoot/root ratio occurred when nitrate was decreased in the presence of glutamine (Fig. 2d).

Metabolites were measured in the shoot and roots as flowering commenced. Low nitrate in the medium led to a decrease of the internal nitrate pool (Fig. 2e), and a general increase of amino acids (Fig. 2f). The latter was partly due to an increase of glutamine, but analyses of the amino acid composition revealed that the levels of most other amino acids were unaltered or increased slightly in low nitrate (data not shown). There was also a small increase in the levels of glucose (Fig. 2g), fructose (not shown), sucrose (Fig. 2h) and starch (Fig. 2i), compared to plants grown on higher nitrate.

For comparison, C24 was also grown with 0.5 and $10 \mathrm{mM}$ nitrate in the absence of glutamine (right hand side of the panels in Fig. 2). In these conditions, low nitrate did 
Fig. 2 Influence of nitrate on the transition to flowering and metabolite levels in the Arabidopsis accession C24 grown with glutamine as a constitutive N source. Plants were grown on medium supplemented with $4 \mathrm{mM}$ glutamine and 1 (grey), 10 (red) or 35 (blue) $\mathrm{mM}$ nitrate, or on non-glutamine supplemented medium with 0.5 (yellow) or 10 (brown) $\mathrm{mM}$ nitrate, in a $12 \mathrm{~h}$ light/12 $\mathrm{h}$ dark photoperiod $\left(120 \mu \mathrm{mol} \mathrm{m}^{-2} \mathrm{~s}^{-1}\right)$ at $20^{\circ} \mathrm{C}$. The percentage of plants with a visible floral bud was scored each day after germination (a). On the day when about $30 \%$ of the plants had a visible floral bud, all plants with a floral bud were harvested. This corresponded to 22, 26 and 30 days for plants on 1,10 and $35 \mathrm{mM}$ nitrate, respectively (the plant age at harvest is noted above). Key colours corresponding to the different treatments mentioned above are similar to panel a, but in this case it is necessary to differentiate between shoot (clear) and root (hatched) tissues. This material was analysed to determine leaf number (b), shoot fresh weight $(\mathrm{FW}, \mathbf{c})$ and root FW (not shown), from which the shoot/ root ratio (d) was calculated.

The shoots and roots were also analysed for nitrate (e), total amino acids (f), glucose (g), sucrose (h) and starch (i). Metabolite levels in the shoot and root are shown as plain and hatched bars, respectively. The results are the mean $\pm \mathrm{SE}$ of $10-15$ individual plants per treatment

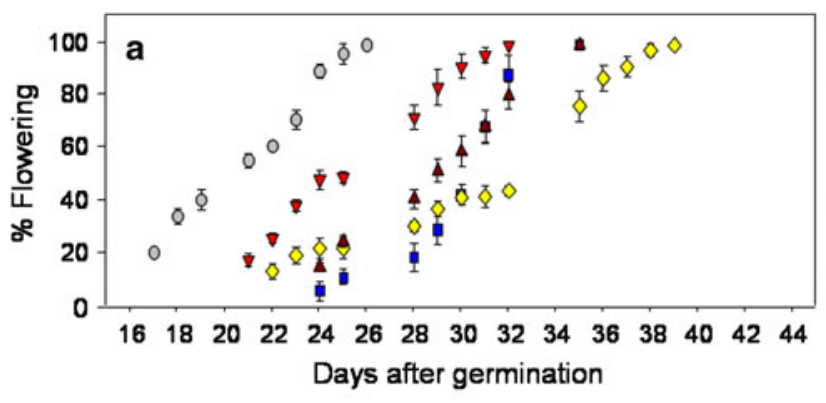

$1 \mathrm{mM}$ Nitrate / $4 \mathrm{mM}$ GIn

$\nabla 10 \mathrm{mM}$ Nitrate / $4 \mathrm{mM}$ GIn

$35 \mathrm{mM}$ Nitrate / $4 \mathrm{mM}$ GIn

$0.5 \mathrm{mM}$ Nitrate $/ 0 \mathrm{mM}$ GIn

$10 \mathrm{mM}$ Nitrate $/ 0 \mathrm{mM}$ GIn

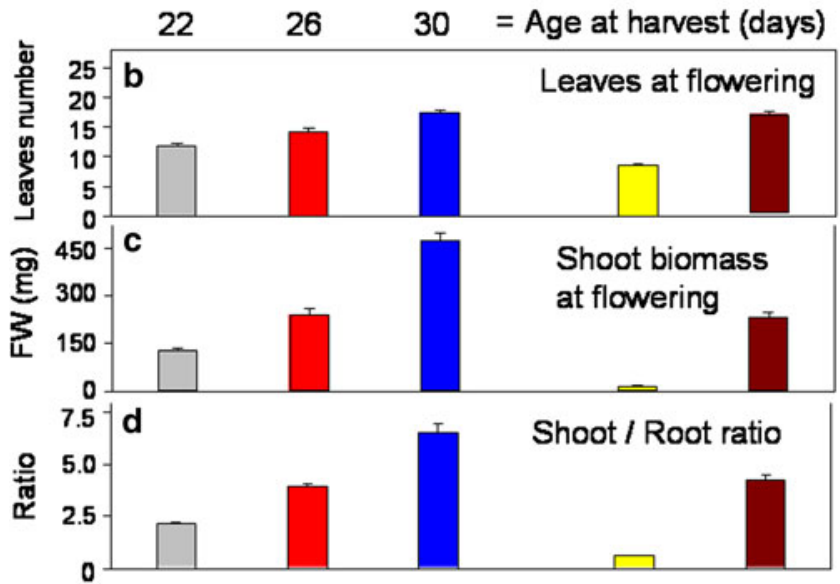

$1 \mathrm{mM}$ Nitrate $/ 4 \mathrm{mM}$ Gln Shoot एट $1 \mathrm{mM}$ Nitrate $/ 4 \mathrm{mM}$ Gln Root

$10 \mathrm{mM}$ Nitrate $/ 4 \mathrm{mM}$ Gin Shoot $10 \mathrm{mM}$ Nitrate $/ 4 \mathrm{mM}$ Gln Root $35 \mathrm{mM}$ Nitrate $/ 4 \mathrm{mM}$ Gin Shoot $35 \mathrm{mM}$ Nitrate $/ 4 \mathrm{mM}$ Gln Root $\Longrightarrow 0.5 \mathrm{mM}$ Nitrate $10 \mathrm{mM}$ Gln Shoot $0.5 \mathrm{mM}$ Nitrate $/ 0 \mathrm{mM}$ Gin Root
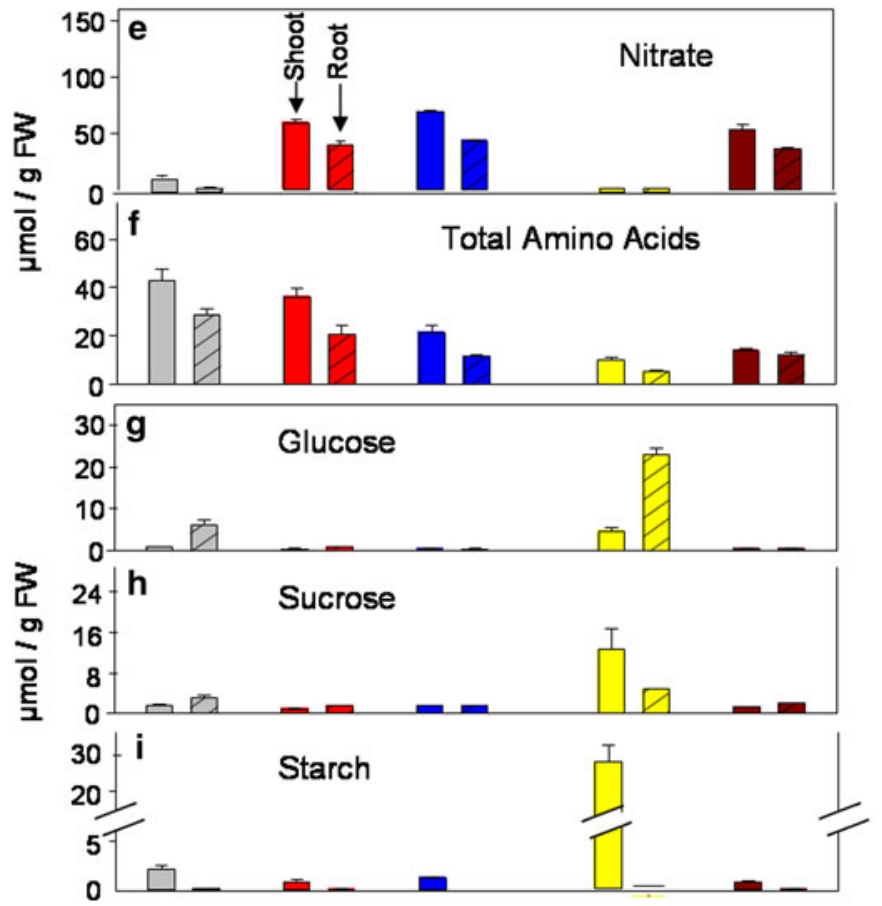

not lead to earlier flowering with respect to time (Fig. 2a), but it did lead to earlier flowering when this is related to leaf number or shoot weight basis (Fig. 2b, c). The acceleration of flowering by low nitrate is masked when flowering is scored on a time basis, because growth is much slower. The impact of external nitrate on internal nitrate levels was similar to that seen in the presence of glutamine (Fig. 2e). The levels of amino acids were lower than in the presence of glutamine, and decreased slightly in low nitrate. The levels of carbohydrates in low nitrate were much higher in the absence of glutamine. This is probably due to the very slow rate of growth in these conditions. 

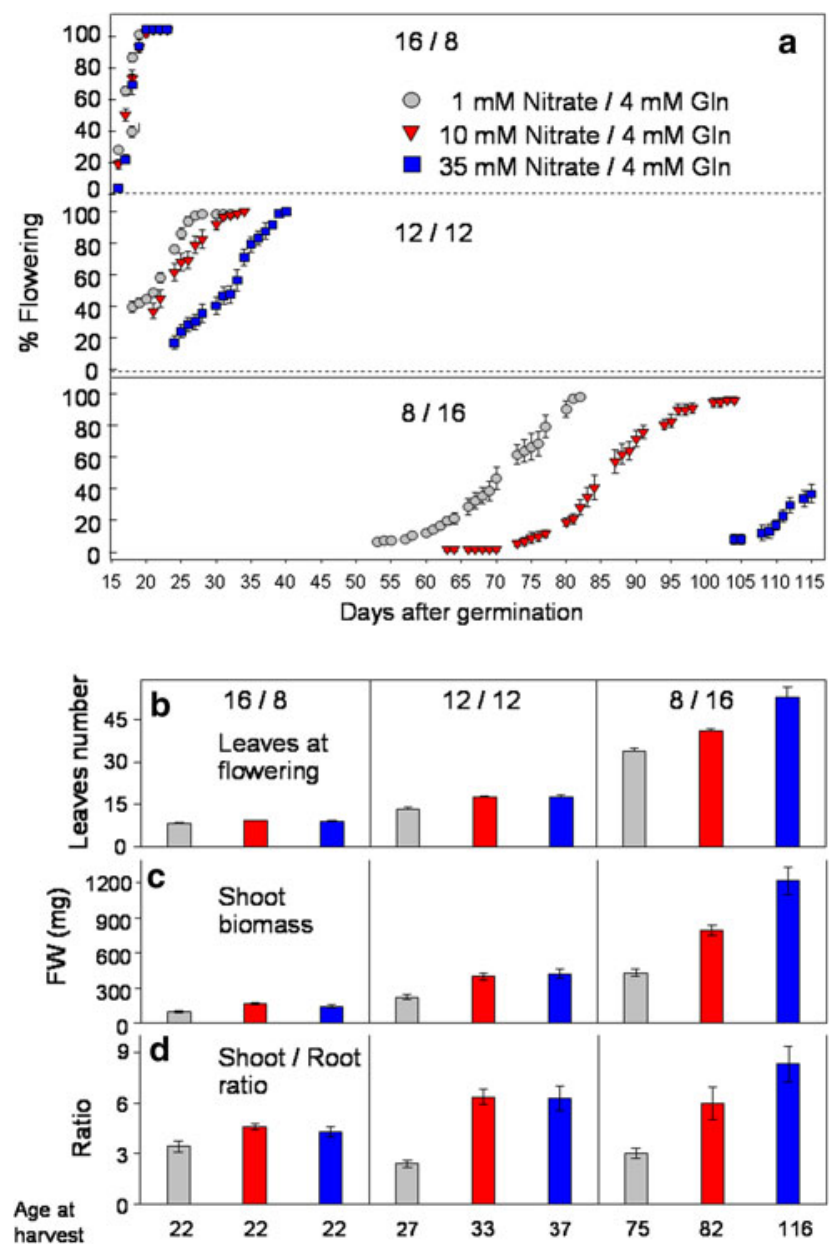

Fig. 3 Influence of nitrate on the transition to flowering and metabolite levels in the Arabidopsis accession Col-0 grown with glutamine as a constitutive $\mathrm{N}$ source in long, neutral and short-day conditions. Plants were grown on 1,10 or $35 \mathrm{mM}$ nitrate in the presence of $4 \mathrm{mM}$ glutamine, at $20^{\circ} \mathrm{C}$ and a light intensity of $\left(120 \mu \mathrm{mol} \mathrm{m} \mathrm{m}^{-2} \mathrm{~s}^{-1}\right)$ in a $16 \mathrm{~h}$ light $/ 8 \mathrm{~h}$ dark, $12 \mathrm{~h} \mathrm{light} / 12 \mathrm{~h}$ dark or $8 \mathrm{~h}$ light/16 h dark photoregime (long, neutral and short days, respectively). The percentage of plants with a visible floral bud was scored each day after germination (a). On the day when about $30 \%$ of the plants had a visible floral bud, all plants with a floral bud were harvested. This was after 22 days for all plants growing in a $16 / 8$ cycle, after 27,33 and 37 days for plants growing in a 12/12 cycle on 1,10 and $35 \mathrm{mM}$ nitrate, respectively, and after 75,82 and 116 days for plants growing in a $8 / 16$ cycle in 1,10 and $35 \mathrm{mM}$ nitrate. This material was used to determine leaf number (b), shoot FW at the transition to flowering $(\mathbf{c})$, the shoot/root ratio (d), nitrate (e), total amino acids (f), glucose (g), sucrose (h) and starch (i). For details and colour scheme, see the legend to Fig. 2. The results are the mean \pm SE of $10-15$ individual plants per treatment

Interaction of nitrate with the photoperiod

Figure 3 shows a more extensive experiment in which the accession Col-0 was grown in long (16/8), neutral (12/12) or short $(8 / 16)$ day conditions in the presence of 1,10 or $35 \mathrm{mM}$ nitrate on glutamine-supplemented medium. As in the experiment of Fig. 2, when circa $30 \%$ of the plants in a given treatment had floral buds these plants were harvested for further analyses, and the remaining plants were scored visually for the remainder of the experiment. The times of harvest are noted in the legend of Fig. 3.

As expected, on high nitrate flowering occurred earlier in long-day conditions than in neutral or short-day conditions (Fig. 3a). Low nitrate did not alter the flowering time in long days, but led to earlier flowering in neutral conditions, and under short-day conditions, flowering was more rapid in nitrate-limiting conditions (Fig. 3a). Leaf number and shoot biomass at flowering were unaffected by nitrate in long days, but were decreased by low nitrate in neutral and short days (Fig. 3b, c). The shoot/root ratio decreased in low nitrate, especially in neutral and short-day conditions (Fig. 3d).

Using the procedure outlined above, we estimated that plants growing on 1,10 and $35 \mathrm{mM}$ nitrate had average relative growth rates of $0.21,0.24$ and 0.23 in a $16 / 8$ cycle, $0.21,0.18$ and 0.17 in a $12 / 12$ cycle, and $0.085,0.082$ and 0.063 in a $8 / 16$ cycle. Thus, inclusion of glutamine in the medium reverses the inhibition of growth of Col-0 in low nitrate, as already seen for C24.

Analyses of plants harvested when flowering was just starting in each treatment showed that internal nitrate fell to low levels in the $1 \mathrm{mM}$ nitrate treatment in all of the photoperiod regimes, and remained high in the 10 and $35 \mathrm{mM}$ nitrate treatments in all three photoperiod regimes (Fig. 3e). The differential response of flowering to nitrate in the three photoperiods is therefore not due to day-lengthdependent changes of internal nitrate. The trend to slightly increased levels of amino acids (Fig. 3f) and increased levels of carbohydrates (Fig. 3g-i) in low nitrate noted for C24 is confirmed in Col-0. This trend is seen in all three photoregimes. As expected, carbohydrates were lower in short days than in neutral or long-day conditions. Amino acids were also lower; this may be due to a restriction on nitrogen metabolism due to a lower supply of carbon in short-day conditions (Matt et al. 1998).

Influence of nitrate on flowering in mutants in known floral induction pathways

Figure 4 summarizes a set of experiments with mutants and transgenic plants altered in the activity of the autonomous, GA, photoperiod or vernalization floral induction pathways, and with transgenic plants with lesions that affect the floral integrators. All these experiments were carried out in a $12 \mathrm{~h}$ light/12 $\mathrm{h}$ dark photoregime, with plants growing on nutrient medium supplemented with $4 \mathrm{mM}$ glutamine and provided with 1,10 or $35 \mathrm{mM}$ nitrate. Some of the mutants are in the Laer background, and some in the Col-0 background (see legend). Both wild types show a weak response to nitrate in these conditions. The complete data set is 
Fig. 3 continued
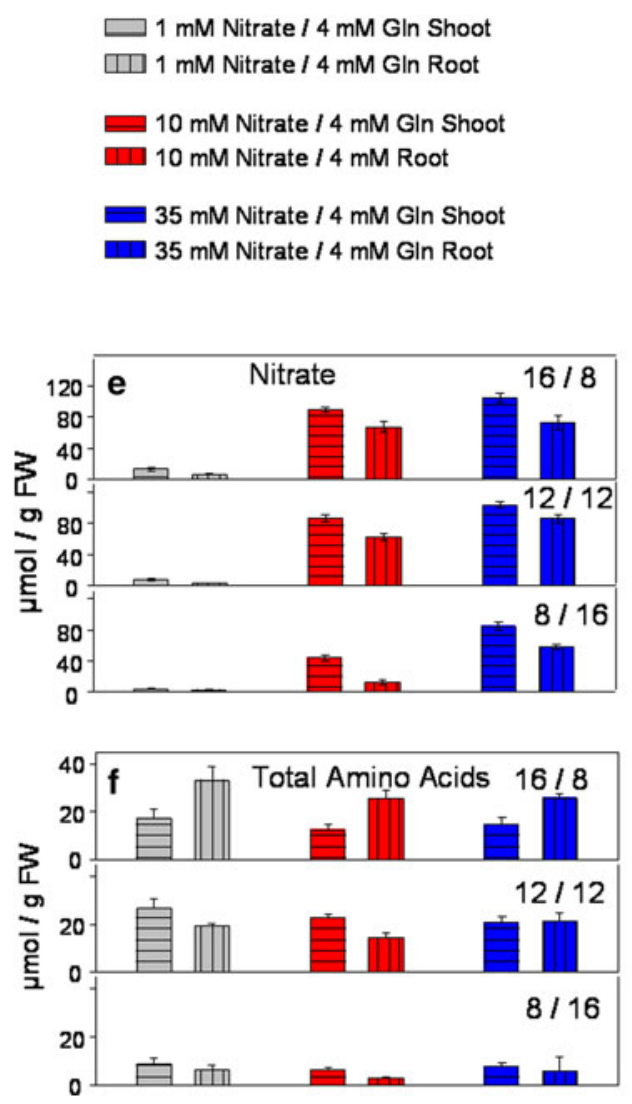
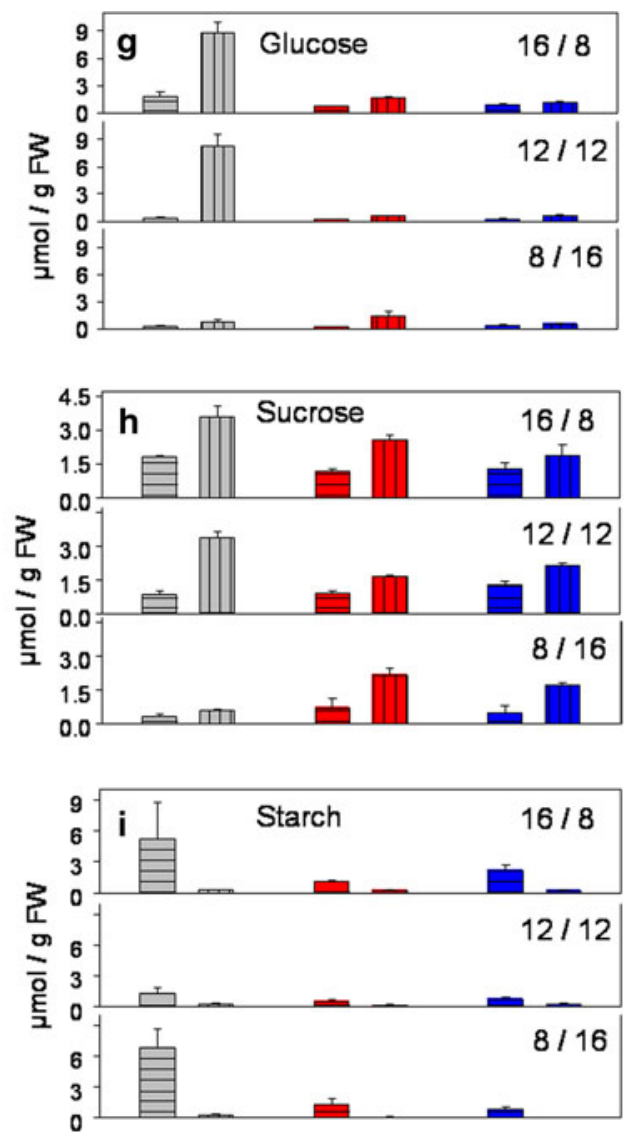

provided in the supplemental material (Supplemental Table S1).

As expected, flowering was delayed in mutants in the autonomous pathway (fwa-1, fve-1, fy-1) (Fig. 4a, see Supplemental Fig. S2 for more data) and a CONSTANS knock-out mutant ( $\mathrm{co}-2 \mathrm{tt} 4$ ) (Fig. 4c, see also Fig. $5 \mathrm{c}$ ) compared to the corresponding wild type. Mutants in the GA pathway (gai, gal-3) (Fig. 4b, see Supplemental Fig. $\mathrm{S} 3$ for more data) only showed a tendency. The co-2 mutant that was used carries the transparent testa4 (tt4) mutation (Putterill et al. 1995; Onouchi et al. 2000). This causes a white seed colour phenotype and was used as a visible marker to indicate the presence of the co2 mutation, but should not affect flowering time. These mutants showed a clear tendency to flower more rapid in low nitrate. This response was retained but not strengthened in the GA-pathway mutants. The response to nitrate was significant in the autonomous pathway mutants fwa- $1, f y-1$, where it was more marked than in the corresponding wild type.

The triple mutant $f c a l$ co-2 gal-3 is compromised in photoperiod, autonomous and GA-dependent flowering, and does not flower under either short- or long-day conditions (Reeves and Coupland 2001). No floral buds were seen when this triple mutant was grown for up to 90 days in the presence of $35 \mathrm{mM}$ nitrate (Figs. 4d, 6). Strikingly, flowering occurred after ca. 75 and 50 when nitrate was decreased to 10 and $1 \mathrm{mM}$, respectively.

The photoperiod, GA and autonomous pathways act by inducing floral integrators like $F T, F D, S O C 1, T F L$ and $L F Y$ (Fig. 1). FD and SOCl have been implicated in the signalling pathway downstream of $F T$, while $T F L$ is thought to antagonise $L F Y$. Low nitrate accelerated flowering in $f t-7, f d-1, l f y$, and $t f l-1$ single mutants (Figs. $4 \mathrm{e}, 5$ ). The only exception was soc1-1, where flowering was hardly delayed. The latter experiment was repeated three times (Figs. 4e, 5). Flowering was strongly delayed in the ft-7 socl-1 double mutant (Figs. 4e, 5). The response to nitrate was qualitatively stronger after repressing some of these floral integrators, including $f t-7$ single mutant and the ft-7 soc $1-1$ double mutant. These results suggest low nitrate promotes flowering via a mechanism that operates independently of the photoperiod, GA and autonomous floral induction pathways, and that enters downstream of the known floral integrators.

The finding that the response to nitrate is stronger in co-2 $t t 4$, the $f t-7$ soc $1-1$ double mutant and the fcal co-2 gal-3 triple mutant could be explained if nitrate acts in 

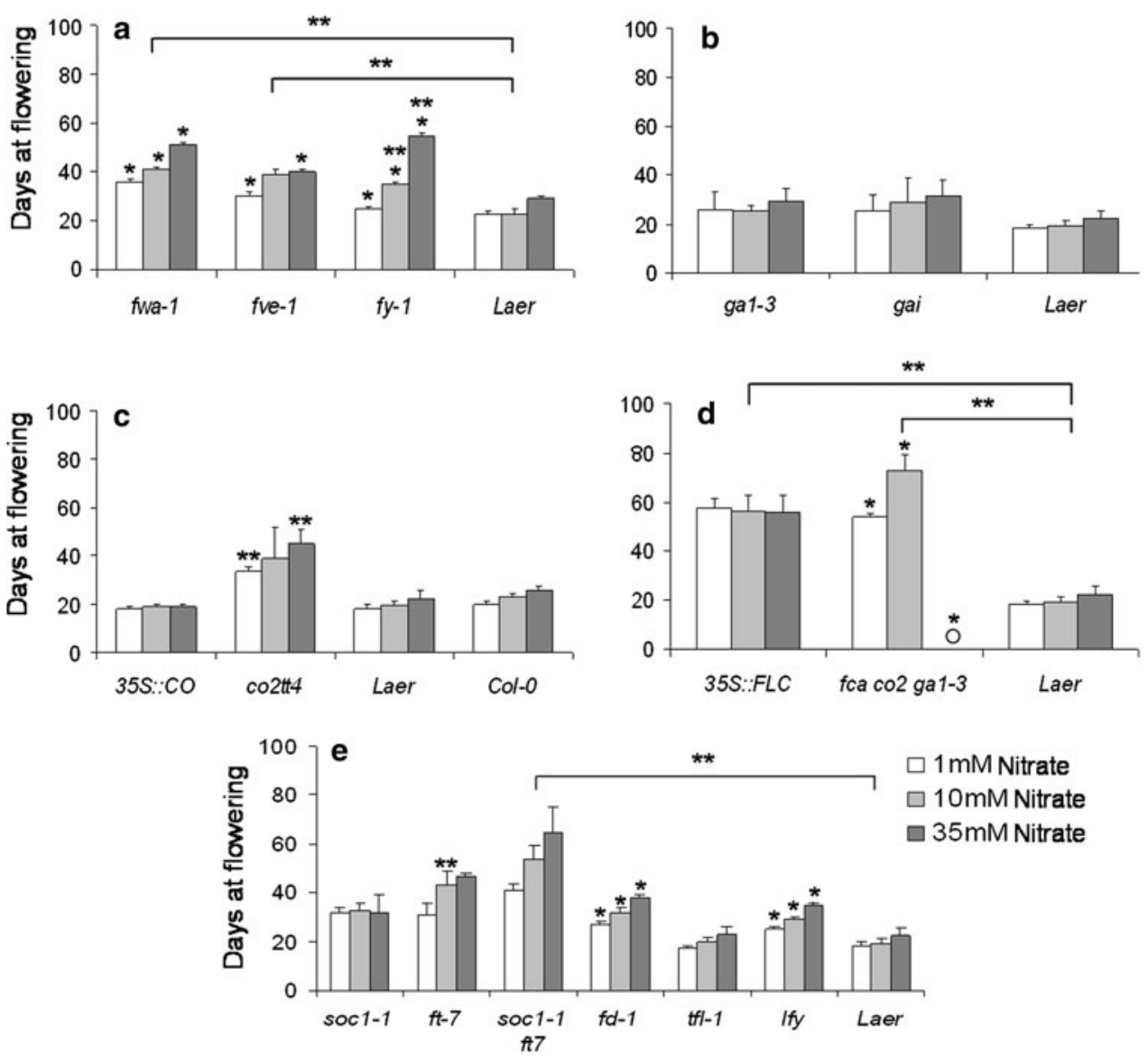

Fig. 4 Summary of the response of flowering to nitrate in mutants in the floral induction pathways and the floral integrators. The percentage of plants with a visible floral bud was scored each day after germination and, in order to get an overview of the flowering time for the different genotypes, the time at which $30 \%$ of the plants induced to flower is represented as the mean $\pm \mathrm{SD}$. All genotypes were grown on 1,10 or $35 \mathrm{mM}$ nitrate in the presence of $4 \mathrm{mM}$ glutamine as a constitutive $\mathrm{N}$ source in a $12 \mathrm{~h}$ light/12 h dark (ca. $120 \mu \mathrm{mol} \mathrm{m} \mathrm{m}^{-2} \mathrm{~s}^{-1}$ ) at $20^{\circ} \mathrm{C}$. a Autonomous pathway (fwa-1, fve-1, $f y-1$; see supplemental Fig. S2 for the original data), $\mathbf{b}$ gibberellic acid pathway (gai, gal-3; see Supplemental Fig. S3 for the original data), c photoperiod pathway $(35 S:: C O, c o 2 t t 4$; see Fig. 5 for the original data), d constitutive overexpression of $F L C(35 S:: F L C)$, e the $f c a c o 2$

parallel with other signalling pathways, and its impact can be more clearly detected when their pathways are inhibited. In this case, constitutive activation of other floral induction pathways should override the effect of low nitrate. As already noted, nitrate has a strong impact on flowering time in short days, but little effect in long days when the photoperiod pathway is activated. This indicates that nitrate acts in parallel to and is redundant with the photoperiod pathway. Flowering is also independent of the nitrate supply in $35 S:: C O$ mutants, where the photoperiod pathway is constitutively activated (Fig. 5b). The autonomous pathway and the vernalisation ga1-1 triple mutant (see Fig. 6) and floral integrators lying downstream or $C O$ and $F L C$ (ft-7, soc1-1, ft-7 soc1-1, fd-1, lfy, tfl-1; see Fig. 5; supplemental Fig. S2 for the original data). The wild-type background was Laer for all the mutants. The response in wild-type Laer and wild-type Col-0 is shown for comparison. All experiments were performed with 11-22 individual plants per treatment. Open circle means that no plant showed floral bud in that condition. Response to different nitrate concentrations was analysed for each genotype $(* P<0.05$, determined with one-way ANOVA for independent samples). **Pairwise significant differences between means (relative to wild-type Laer) determined with one-way ANOVA followed by a multiple comparison test (Tukey's honestly significant difference test)

pathways both act by repressing FLC (Fig. 1). The interaction of nitrate with these pathways was investigated in $35 S:: F L C$ mutants, which have constitutive overexpression of $F L C$ and strongly delayed flowering. The response to nitrate was abolished in $35 S:: F L C$ mutants (Fig. 4d).

Summarizing, the promotion of flowering by low nitrate becomes more marked when the other signalling pathways are attenuated or inhibited, but is blocked by constitutive overexpression of $F L C$. These observations are consistent with the idea that nitrate modulates flowering time via a pathway that acts in parallel with the autonomous, 


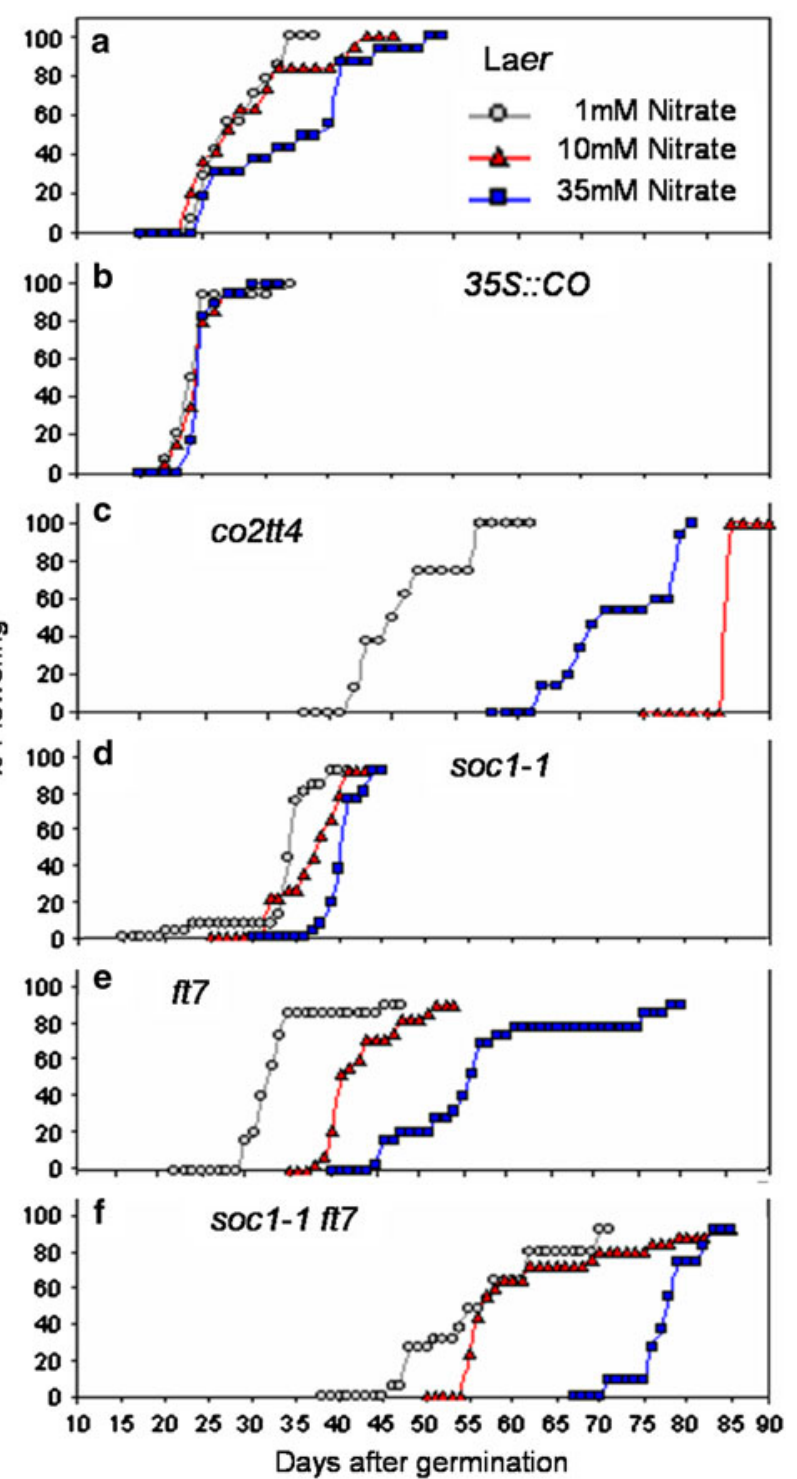

Fig. 5 Response to nitrate in mutants in the photoperiod pathway, and in floral integrators lying downstream of this pathway. All genotypes were grown on 1,10 or $35 \mathrm{mM}$ nitrate in the presence of $4 \mathrm{mM}$ glutamine as a constitutive $\mathrm{N}$ source in a $12 \mathrm{~h}$ light/12 h dark (ca. $120 \mu \mathrm{mol} \mathrm{m} \mathrm{m}^{-2} \mathrm{~s}^{-1}$ ) at $20^{\circ} \mathrm{C}$. a Laer wild-type, b $35 \mathrm{~S}:: \mathrm{CO}$, c co2 $t t 4$, d soc $1-1$, e $f t-7$ and $\mathbf{f} f t-7$ soc $1-1$ double mutant. All experiments were performed with 11-22 individual plants per treatment. For colour scheme, see Fig. 2

photoperiod and GA pathways, that enters downstream of the known floral integrators, but is repressed by $F L C$.

Response to low phosphate

To investigate whether other nutrients modulate flowering via a similar mechanism to nitrate, wild-type Laer and the fcal co-2 gal-3 triple mutant were grown in the presence of excess $(3 \mathrm{mM})$ and limiting $(0.2 \mathrm{mM})$ phosphate

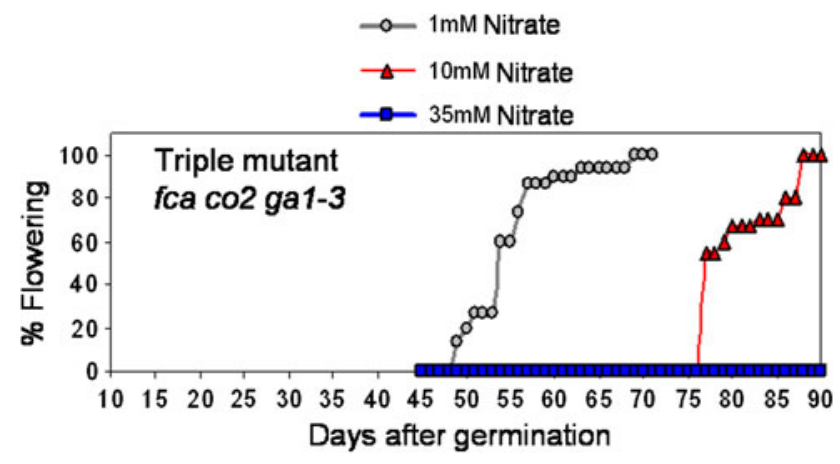

Fig. 6 Response to nitrate in the $f c a c o 2$ gal-3 triple mutant. The triple mutant was grown on 1 (grey circle), 10 (red triangle) or 35 (blue square) $\mathrm{mM}$ nitrate in the presence of $4 \mathrm{mM}$ glutamine as a constitutive $\mathrm{N}$ source in a $12 \mathrm{~h}$ light/12 h dark (ca. $120 \mu \mathrm{mol} \mathrm{m} \mathrm{m}^{-2} \mathrm{~s}^{-1}$ ) at $20^{\circ} \mathrm{C}$. $12-15$ individual plants were used per treatment. The response in wild-type Laer is shown in Fig. 5a. The experiment was performed three times with similar results. For colour scheme, see Fig. 2

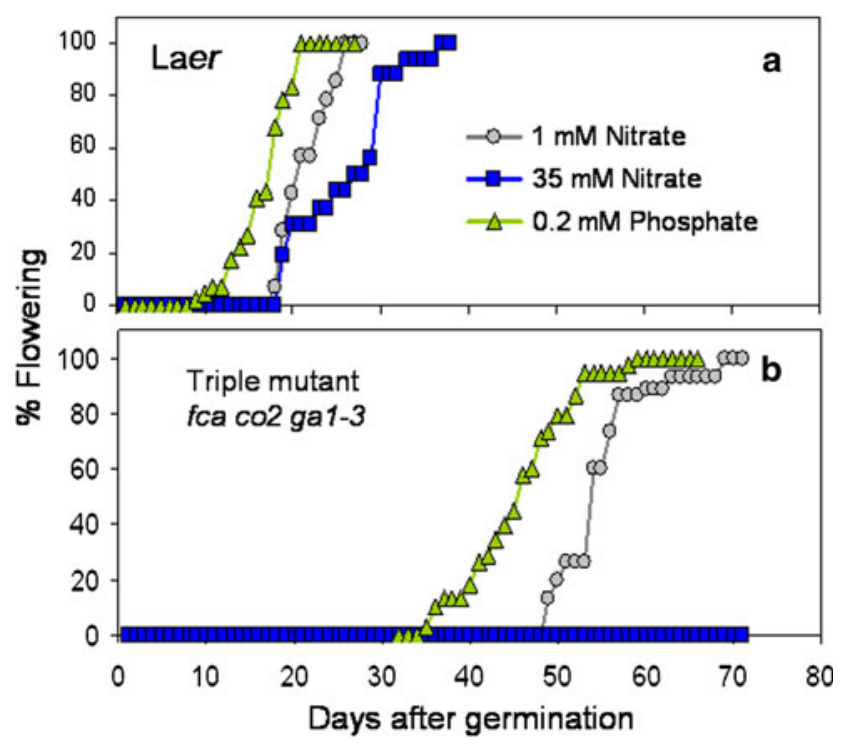

Fig. 7 Response of flowering time to low phosphate. a Laer, wild type grown on $1 \mathrm{mM} \mathrm{KNO}_{3}(n=14), 35 \mathrm{mM} \mathrm{KNO}_{3}(n=22)$ or $0.2 \mathrm{mM} \mathrm{KH}_{2} \mathrm{PO}_{4}(n=41)$. b fca co 2 gal-3 triple mutant on $1 \mathrm{mM}$ $\mathrm{KNO}_{3}(n=15), 35 \mathrm{mM} \mathrm{KNO}_{3}(n=14)$ or $0.2 \mathrm{mM} \mathrm{KH} \mathrm{KHO}_{4}$ $(n=48)$. Treatments of $1 \mathrm{mM}$ and $35 \mathrm{mM} \mathrm{KNO}_{3}$ contained $3 \mathrm{mM}$ phosphate, so that, were used for comparison to the $0.2 \mathrm{mM}$ phosphate treatment. All mediums were supplemented with $4 \mathrm{mM}$ glutamine. Plants were grown in a $12 \mathrm{~h}$ light/12 $\mathrm{h}$ dark photoperiod at $20^{\circ} \mathrm{C}$ day/night and $12 \mathrm{~h}$ of light period

(Fig. 7). Low phosphate led to earlier flowering in wildtype Laer (Fig. 7a). Flowering in the triple mutant was suppressed for at least 75 days in high phosphate (plants never flowered), but was initiated after 30-50 days in $0.2 \mathrm{mM}$ phosphate (Fig. 7b). 
Response to abiotic stresses

General stress can also lead to early flowering. To provide further evidence that low nitrate does not act via a general stress pathway, we investigated whether abiotic stresses can trigger flowering in the $f c a l$ co-2 gal-3 triple mutant (Fig. 8). High light (Fig. 8a), high temperature (Fig. 8b), photochilling (Fig. 8c) and continuous light treatments (Fig. 8d) lead to earlier flowering in wild-type Laer. Except for photochilling, the effect was similar to or larger than the effect of nitrate in wild-type plants (see e.g., Fig. 5a). None of these treatments induced flowering in the triple mutant.

\section{Discussion}

The experiments in this paper were carried out to investigate how nitrate regulates flowering, by exploiting genetic tools available in Arabidopsis. $\mathrm{N}$ deficiency often induces early flowering (Klebs 1913; Dickens and van Staden 1988; Bernier et al. 1993). Limiting $\mathrm{N}$ leads to many changes in the plant including the depletion of nitrate, ammonium and amino acids, decreased protein, accumulation of carbohydrates especially starch, decreased growth, a change in allocation to favour root growth relative to shoot growth, and early senescence of old leaves. To separate the specific effects of nitrate from more general changes due $\mathrm{N}$ deficiency, we used glutamine as a constitutive $\mathrm{N}$ supply, and varied the nitrate in the medium. Plants growing on $1 \mathrm{mM}$ nitrate contained low internal nitrate, but showed similar rates of growth to plants in 10 and $35 \mathrm{mM}$ nitrate, and had slightly elevated amino acid levels. This shows that glutamine can efficiently replace nitrate as an $\mathrm{N}$ source.

Growth in low $\mathrm{N}$ typically leads to a decrease of the shoot:root ratio (Marschner 1995). This decrease is partly due to nitrate signalling. Thus, the shoot:root ratio is high in low-NR mutants where organic $\mathrm{N}$ is low but nitrate is high (Scheible et al. 1997b), and lateral root growth is directly regulated by nitrate (Zhang and Forde 1998; Zhang et al. 1999; Tian et al. 2008). The decrease of the shoot:root ratio in our experiments provides evidence that nitrate signalling is operating in our growth system.

Plants grown on low nitrate flowered earlier than plants grown on high nitrate in this glutamine-supplemented system. Flowering was accelerated, irrespective of whether it was scored relative to time, leaf number or shoot fresh weight. This acceleration was observed in three different accessions (Col-0, Laer, C24). When C24 (data not shown) or the other accessions were grown on low and high nitrate in the absence of glutamine supplementation, a more complicated response was found. While low nitrate still led to earlier flowering on a leaf number or shoot fresh weight

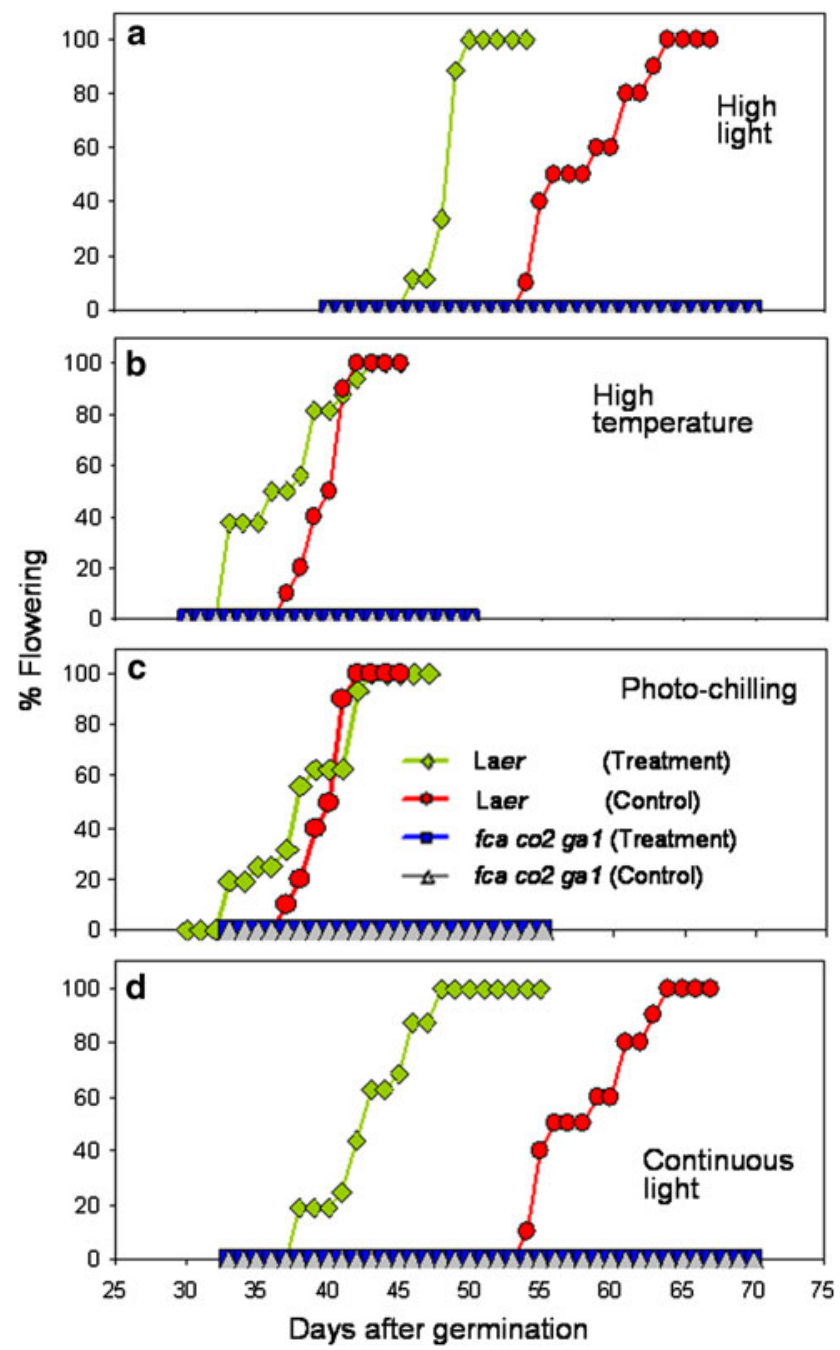

Fig. 8 Response of flowering time to abiotic stress in wild-type Laer and the $f c a$ co 2 gal-3, triple mutant. Controls were grown in a $12 \mathrm{~h}$ light $/ 12 \mathrm{~h}$ dark photoregime (ca. $120 \mu \mathrm{mol} \mathrm{m}^{-2} \mathrm{~s}^{-1}$ ) and $20^{\circ} \mathrm{C}$, unless stated otherwise. a High light. Treatment $800 \mu \mathrm{mol} \mathrm{m}^{-2} \mathrm{~s}^{-1}$ in an $8 \mathrm{~h} \mathrm{light} / 16 \mathrm{~h}$ dark photoregime. Control ca. $120 \mu \mathrm{mol} \mathrm{m} \mathrm{m}^{-2} \mathrm{~s}^{-1}$. Laer high light, $n=16$; Laer control, $n=10$; fcaco2gal-3 high light, $n=16$; fcaco 2 gal -3 control, $n=16$. b High temperature. Treatment $26^{\circ} \mathrm{C}$ day $/ 22^{\circ} \mathrm{C}$ night, $12 \mathrm{~h}$ light $/ 12 \mathrm{~h}$ dark; $120 \mu \mathrm{mol} \mathrm{m}{ }^{-2} \mathrm{~s}^{-1}$. Control $20^{\circ} \mathrm{C}$ day $/ 20^{\circ} \mathrm{C}$ night, $12 \mathrm{~h}$ light $/ 12 \mathrm{~h}$ dark; $120 \mu \mathrm{mol} \mathrm{m} \mathrm{m}^{-2} \mathrm{~s}^{-1}$. Laer high temperature, $n=16$; Laer control, $n=10$; fcaco2gal-3 high temperature, $n=16$; fcaco2gal3 control, $n=16$. c Photochilling. Treatment $16^{\circ} \mathrm{C}$ day and night; $800 \mu \mathrm{mol} \mathrm{m}{ }^{-2} \mathrm{~s}^{-1}, 12 \mathrm{~h} \mathrm{light} / 12 \mathrm{~h}$ dark photoregime. Control $20^{\circ} \mathrm{C}$ day $/ 20^{\circ} \mathrm{C}$ night, $12 \mathrm{~h}$ light $/ 12 \mathrm{~h}$ dark; $120 \mu \mathrm{mol} \mathrm{m}{ }^{-2} \mathrm{~s}^{-1}$. Laer photochilling, $n=16$; Laer control, $n=10$; fcaco2gal-3 photochilling, $n=16$; fcaco2gal-3 control, $n=16$. d Continuous light. Treatment continuous light, $120 \mu \mathrm{mol} \mathrm{m} \mathrm{m}^{-2} \mathrm{~s}^{-1}, 20^{\circ} \mathrm{C}$. Control $20^{\circ} \mathrm{C}$ day $/ 20^{\circ} \mathrm{C}$ night, $8 \mathrm{~h}$ light $/ 16 \mathrm{~h}$ dark; $120 \mu \mathrm{mol} \mathrm{m} \mathrm{m}^{-2} \mathrm{~s}^{-1}$. Laer continuous light, $n=16$; Laer control, $n=10$; fcaco2gal-3 continuous light, $n=16$; fcaco2gal-3 control, $n=16$

basis, flowering was slightly delayed in time. This is probably due to the very slow growth of the plants. Measurements of metabolites in plants grown in the glutaminesupplemented growth system confirmed that the internal 
nitrate decreased to low levels in the low nitrate treatment, while amino acids remained high. This provides evidence that the signal that regulates flowering is related to nitrate itself, or a metabolite that is formed from nitrate but lies upstream of glutamine. At least in these conditions, amino acids do not appear to serve as controlling factors of the floral transition (Corbesier et al. 1998, 2001; Suárez-López et al. 2001).

Several floral induction signalling pathways have been genetically characterised, including the photoperiod, the temperature, the gibberellin and the autonomous pathways. Mutants and transformants that are attenuated or disrupted in these signalling pathways still showed an acceleration of flowering in low nitrate. There was an especially strong response in the fca-1 co-2 gal-3 triple mutant, which is blocked in the photoperiod, autonomous and gibberellin floral signalling pathways. This triple mutant, which usually does not flower (Reeves and Coupland 2001), flowered after 45-50 days in low nitrate. The photoperiod and GA pathways converge on a common set of floral pathway integrators, including FT, SOC1 and LFY (Blázquez and Weigel 2000; Lee et al. 2000; Samach et al. 2000; Moon et al. 2003; Boss et al. 2004). Mutants in ft7 and lfy as well as the $f t 7$ soc $1-1$ double mutant still showed an acceleration of flowering in low nitrate. These results indicate that nitrate acts by a separate signalling pathway, which enters downstream of the photoperiod, temperature, autonomous and vernalisation signalling pathways.

Although nitrate appears to act via a separate pathway, it interacts with other floral induction pathways. Nitrate has no detectable effect in long days or in $C O$ overexpressing lines where photoperiod signalling is strongly activated. It has a particularly marked effect on flowering in short days or in $c o 2$ and $f t$ mutants where photoperiod signalling is weakened or abolished. The vernalisation and autonomous pathways act by epigenetic silencing of FLC (Simpson and Dean 2002; Sung and Amasino 2004; Alexandre and Hennig 2008), which itself acts as a negative regulator of $F T$ and SOC1. Correspondingly, overexpression of FLC overrides the photoperiod, autonomous and gibberellin floral induction pathways. Constitutive overexpression of $F L C$ prevented early flowering in low nitrate. This implies that overexpression of $F L C$ from the CaMV $35 S$ promoter inhibits unknown components in the nitrate-floral signalling pathway. Interestingly, low nitrate still induced earlier flowering in autonomous pathway mutants (see above), even though such mutants contain elevated FLC mRNA levels (Michaels and Amasino 1999; Sheldon et al. 2000; Simpson and Dean 2002, Simpson et al. 2004). This difference might be due to the much higher levels of FLC expression in $35 S:: F L C$ plants, or to differences in the spatial patterns of expression of $F L C$ expression between $35 S:: F L C$ plants and autonomous pathway mutants. An alternative explanation is that nitrate is able to repress $F L C$ when this floral repressor is expressed from its own promoter but not when it is constitutively and strongly expressed from the CaMV $35 S$ promoter. However, this seems unlikely to be the sole explanation, because $F L C$ is thought to act by repressing floral integrators like $F T$, $S O C 1$ and $L F Y$, and the response of flowering to nitrate is retained and even accentuated in $l f y$ and $f t-7$ mutants and in $f t-7$ soc $1-1$ double mutants. There is also no evidence that low nitrate decreases FLC transcript levels (Scheible et al. 2004; data not shown). Therefore, we can conclude that the effect of nitrate is dependent on FLC levels and perhaps there are some ecotypes (as C24) with an extreme vernalisation requirement that should be insensitive to nitrate levels (with respect to flowering time).

Recently, evidence has been adduced that further pathways operate to induce flowering in response to stress, including a salicylic acid that leads to early flowering under UV-C stress and interacts with FLC, FT and some components of the autonomous pathway (Martinez et al. 2004; Wada et al. 2010) and a high-temperature pathway that involves some components of the autonomous pathway (Blázquez et al. 2003; Balasubramanian et al. 2006). Several lines of evidence indicate that low nitrate does not act via a general stress pathway. First, nitrate accelerated flowering, even when plants were provided with glutamine and had high levels of amino acids and protein, and rates of growth comparable to those on high nitrate. Second, nitrate still led to early flowering in the fcalco-2gal-3 triple mutant, whereas the acceleration of flowering by several stresses including high temperatures was blocked in this triple mutant. Third, regulation of flowering by salicylic acid pathway is blocked by mutations in the autonomous pathway including fve-3 and $f(a-9$, and probably required increase expression of FT (Martinez et al. 2004), whereas low nitrate still induced flowering in fve and fca mutants, and in the $f t-7$ mutant.

Early flowering in low nutrient conditions provides an escape strategy, by promoting seed set and reproduction when the nutrient supply is exhausted. This may be important for a weed like Arabidopsis. Functionally, it will be closely linked with leaf senescence, to remobilise nutrients from vegetative tissues into seeds. The interaction between nitrate and the photoperiod pathway and other FLC-modulated pathways uncovered in our laboratory experiments is consistent with the idea that the nitratesignalling pathway provides an escape strategy. Thus, photoperiod signalling leads to flowering in long days and allows flowering to be adjusted to the season, irrespective of the $\mathrm{N}$ supply. However, if the $\mathrm{N}$ supply is low, Arabidopsis flowers earlier, even in short days. Similarly, in accessions with a biennial life history, vernalisation is required to inactivate $F L C$ and allow flowering in the 


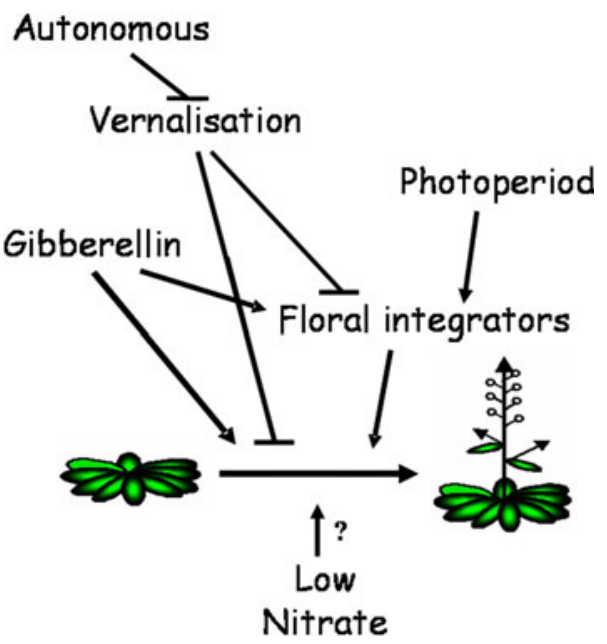

Fig. 9 Schematic model of flowering pathways in Arabidopsis. The nitrate-signalling pathway acts in parallel to and enters downstream of the photoperiod, GA and autonomous pathways and known floral integrators, but can be overridden by these pathways

following spring. The observation that FLC strongly inhibits flowering even in low $\mathrm{N}$ indicates that this strategy may be fairly resilient to changes in $\mathrm{N}$, although studies in biennial accessions are needed to test this prediction.

Summarizing, our results lead to the proposal that nitrate modulates flowering time via a pathway that acts in parallel with the autonomous, photoperiod and gibberellic acid floral induction pathways, enters downstream of the known floral integrators, but is repressed by $F L C$ (see schematic model for flowering pathways in Arabidopsis, Fig. 9). Further elucidation of nitrate-dependent signalling pathway will require the development of an experimental system where it is possible to change $\mathrm{N}$ and generate a synchronized transition to flowering, in order to analyse changes of transcripts and proteins at the shoot apex.

Acknowledgments The work was supported by the Max-PlanckSociety and by the German Ministry for Research and Technology (BMBF) funding the project GABI Verbund Arabidopsis III 'Gauntlets, 'C and Nutrient Signaling: Test Systems, and Metabolite and Transcript Profiles' (0312277A).

Open Access This article is distributed under the terms of the Creative Commons Attribution Noncommercial License which permits any noncommercial use, distribution, and reproduction in any medium, provided the original author(s) and source are credited.

\section{References}

Alboresi A, Gestin C, Leydecker M-T, Bedu M, Meyer C, Truong H-N (2005) Nitrate, a signal relieving seed dormancy in Arabidopsis. Plant Cell Environ 28:500-512

Alexandre CM, Hennig L (2008) FLC or not FLC: the other side of vernalization. J Exp Bot 59:1127-1135
Balasubramanian S, Sureshkumar S, Lempe J, Weigel D (2006) Potent induction of Arabidopsis thaliana flowering by elevated growth temperature. PLos Genet 2:e106

Bernier G, Kinet JM, Sachs RM (1981) The physiology of flowering, volume 1. The initiation of flowers. CRC Press, Boca Raton, FL, p 149

Bernier G, Havelange A, Houssa C, Petitjean A, Lejeune P (1993) Physiological signals that induce flowering. Plant Cell 5:1147-1155

Bläsing OE, Gibon Y, Günther M, Höhne M, Morcuende R, Osuna D, Thimm O, Usadel B, Scheible W-R, Stitt M (2005) Sugars and circadian regulation make major contributions to the global regulation of diurnal gene expression in Arabidopsis. Plant Cell $17: 3257-3281$

Blázquez M (2005) The right time and place for making flowers. Science 309:1024-1025

Blázquez M, Weigel D (2000) Integration of floral inductive signals in Arabidopsis. Nature 404:889-892

Blázquez M, Ahn JH, Weigel D (2003) A thermosensory pathway controlling flowering time in Arabidopsis thaliana. Nat Genet 33:168-171

Boss PK, Bastow RM, Mylne JS, Dean C (2004) Multiple pathways in the decision to flower: enabling, promoting, and resetting. Plant Cell 16(Suppl):S18-S31

Cheng H, Qin L, Lee S, Fu X, Richards DE, Cao D, Luo D, Harberd NP, Peng J (2004) Gibberellin regulates Arabidopsis floral development via suppression of DELLA protein function. Development 131:1055-1064

Corbesier L, Coupland G (2006) The quest for florigen: a review of recent progress. J Exp Bot 57:3395-3403

Corbesier L, Lejeune P, Bernier G (1998) The role of carbohydrates in the induction of flowering in Arabidopsis thaliana: comparison between the wild type and a starchless mutant. Planta 206:131-137

Corbesier L, Havelange A, Lejeune P, Bernier G, Périlleux C (2001) $\mathrm{N}$ content of phloem and xylem exudates during the transition to flowering in Sinapis alba and Arabidopsis thaliana. Plant Cell Environ 24:367-375

Corbesier L, Prinsen E, Jacqmard A, Lejeune P, Van Onckelen H, Périlleux C, Bernier G (2003) Cytokinin levels in leaves, leaf exudate and shoot apical meristem of Arabidopsis thaliana during floral transition. J Exp Bot 54:2511-2517

Crawford NM (1995) Nitrate: nutrient and signal for plant growth. Plant Cell 7:859-868

Dickens CWS, van Staden J (1988) The in vitro flowering of Kalanchöe blossfeldiana Poellniz. I. Role of culture conditions and nutrients. J Exp Bot 39:461-471

Filleur S, Walch-Liu P, Gan Y, Forde BG (2005) Nitrate and glutamate sensing by plant roots. Biochem Soc Trans 33:283-286

Forde BG, Lea PJ (2007) Glutamate in plants: metabolism, regulation, and signalling. J Exp Bot 58:2339-2358

Fritz C, Palacios-Rojas N, Feil R, Stitt M (2006) Regulation of secondary metabolism by the carbon-nitrogen status in tobacco: nitrate inhibits large sectors of phenylpropanoid metabolism. Plant J 46:533-548

Geigenberger P, Lerchl J, Stitt M, Sonnewald U (1996) Phloemspecific expression of pyrophosphatase inhibits long distance transport of carbohydrates and amino acids in tobacco plants. Plant Cell Environ 19:43-55

Gutiérrez RA, Lejay LV, Dean A, Chiaromonte F, Shasha DE, Coruzzi GM (2007) Qualitative network models and genomewide expression data define carbon/nitrogen-responsive molecular machines in Arabidopsis. Genome Biol 8:R7

Hirel B, Le Gouis J, Ney B, Gallais A (2007) The challenge of improving nitrogen use efficiency in crop plants: towards a more central role for genetic variability and quantitative genetics within integrated approaches. J Exp Bot 58:2369-2387 
Hsieh MH, Lam HM, van de Loo FJ, Coruzzi G (1998) A PII-like protein in Arabidopsis: putative role in $\mathrm{N}$ sensing. Proc Natl Acad Sci USA 95:13965-13970

Kamberov ES, Atkinson MR, Ninfa AJ (1995) The Escherichia coli PII signal transduction protein is activated upon binding 2ketoglutarate and ATP. J Biol Chem 270:17797-17807

Kang J, Turano FJ (2003) The putative glutamate receptor 1.1 (AtGLR1.1) functions as a regulator of carbon and nitrogen metabolism in Arabidopsis thaliana. Proc Natl Acad Sci USA. 100:6872-6877

Kim DH, Doyle MR, Sung S, Amasino RM (2009) Vernalization: winter and the timing of flowering in plants. Annu Rev Cell Dev Biol 25:277-299

Klebs G (1913) Über das Verhältnis der Außenwelt zur Entwicklung der Pflanze. Sitz-Ber Akad Wiss Heidelberg Ser B 5:3-47

Koornneef M, Alonso-Blanco C, Peeters AJ, Soppe W (1998) Genetic control of flowering time in Arabidopsis. Annu Rev Plant Physiol Plant Mol Biol 49:345-370

Langridge J (1957) Effect of day-length and gibberellic acid on the flowering of Arabidopsis. Nature 180:36-37

Lea PJ, Azevedo RA (2006) Nitrogen use efficiency. 1. Uptake of nitrogen from the soil. Ann Appl Biol 149:243-247

Lee H, Suh S, Park E, Cho E, Ahn JH, Kim S, Lee JS, Kwon YM, Lee I (2000) The AGAMOUS-LIKE 20 MADS domain protein integrates floral inductive pathways in Arabidopsis. Genes Dev 14:2366-2376

Lee S, Cheng H, King KE, Wang W, He Y, Hussain A, Lo J, Harberd NP, Peng J (2002) Gibberellin regulates Arabidopsis seed germination via $R G L 2$, a $G A I / R G A$-like gene whose expression is up-regulated following imbibition. Genes Dev 16:646-658

Levy YY, Dean C (1998) The transition to flowering. Plant Cell 10:1973-1990

Little DY, Rao H, Oliva S, Daniel-Vedele F, Krapp A, Malamy JE (2005) The putative high-affinity nitrate transporter NRT2.1 represses lateral root initiation in response to nutritional cues. Proc Natl Acad Sci USA 102:13693-13698

Marschner M (1995) Mineral nutrition of higher plants, 2nd edn. Academic Press, London, UK

Martinez C, Pons E, Prats G, León J (2004) Salicylic acid regulates flowering time and links defence responses and reproductive development. Plant J 37:209-217

Matt P, Schurr U, Klein D, Krapp A, Stitt M (1998) Growth of tobacco in short days conditions leads to high starch, low sugars, altered diurnal changes of the Nia transcript and low nitrate reductase activity, and an inhibition of amino acid synthesis. Planta 207:27-41

Michaels SD, Amasino RD (1999) FLOWERING LOCUS C encodes a novel MADS domain protein that acts as a repressor of flowering. Plant Cell 11:949-956

Miller G, Suzuki N, Rizhsky L, Hegie A, Koussevitzky S, Mittler R (2007) Double mutants deficient in cytosolic and thylakoid ascorbate peroxidase reveal a complex mode of interaction between reactive oxygen species, plant development, and response to abiotic stresses. Plant Physiol 144:1777-1785

Moon J, Suh S-S, Lee H, Choi K-R, Bong Hong C, Paek N-C, Kim SG, Lee I (2003) The SOC1 MADS-box gene integrates vernalization and gibberellin signals for flowering in Arabidopsis. Plant J 35:613-623

Moorhead GB, Smith CS (2003) Interpreting the plastid carbon, nitrogen, and energy status. A role for $\mathrm{P}_{\mathrm{II}}$ ? Plant Physiol 133:492-498

Mouradov A, Cremer F, Coupland G (2002) Control of flowering time: interacting pathways as a basis for diversity. Plant Cell 14:S111-S130

Onouchi H, Igeno MI, Perilleux C, Graves K, Coupland G (2000) Mutagenesis of plants overexpressing CONSTANS demonstrates novel interactions among Arabidopsis flowering-time genes. Plant Cell 12:885-900

Putterill J, Robson F, Lee K, Simon R, Coupland G (1995) The CONSTANS gene of Arabidopsis promotes flowering and encodes a protein showing similarities to zinc finger transcription factors. Cell 80:847-857

Reeves RH, Coupland G (2001) Analysis of flowering time control in Arabidopsis by comparison of double and triple mutants. Plant Physiol 126:1085-1091

Remans T, Nacry P, Pervent M, Girin T, Tillard P, Lepetit M, Gojon A (2006) A central role for the nitrate transporter NRT2.1 in the integrated morphological and physiological responses of the root system to nitrogen limitation in Arabidopsis. Plant Physiol 140:909-921

Sakakibara H, Suzuki M, Takei M, Deji A, Taniguchi M, Sugiyama T (1998) A response-regulator homolog possibly involved in N signal transduction mediated by cytokinin in maize. Plant J 14:337-344

Samach A, Onouchi H, Gold SE, Ditta GS, Schwarz-Sommer Z, Yanofsky MF, Coupland G (2000) Distinct roles of CONSTANS target genes in reproductive development of Arabidopsis. Science 288:1613-1616

Scheible WR, Gonzalez-Fontes A, Lauerer M, Müller-Röber B, Caboche M, Stitt M (1997a) Nitrate acts as a signal to induce organic acid metabolism and repress starch metabolism in tobacco. Plant Cell 9:783-798

Scheible WR, Lauerer M, Schulze ED, Caboche M, Stitt M (1997b) Accumulation of nitrate in the shoot acts as a signal to regulate shoot-root allocation in tobacco. Plant J 11:671-691

Scheible WR, Krapp A, Stitt M (2000) Reciprocal diurnal changes of phosphoenolpyruvate carboxylase expression and cytosolic pyruvate kinase, citrate synthase and NADP-isocitrate dehydrogenase expression regulate organic acid metabolism during nitrate assimilation in tobacco leaves. Plant Cell Environ 23:1155-1168

Scheible WR, Morcuende R, Czechowski T, Fritz C, Osuna D, Palacios-Rojas N, Schindelasch D, Thimm O, Udvardi MK, Stitt M (2004) Genome-wide reprogramming of primary and secondary metabolism, protein synthesis, cellular growth processes, and the regulatory infrastructure of Arabidopsis in response to nitrogen. Plant Physiol 136:2483-2499

Schluepmann H, Pellny T, van Dijken A, Smeekens S, Paul M (2003) Trehalose 6-phosphate is indispensable for carbohydrate utilization and growth in Arabidopsis thaliana. Proc Natl Acad Sci USA 100:6849-6854

Sheldon CC, Rouse DT, Finnegan EJ, Peacock WJ, Dennis ES (2000) The molecular basis of vernalization: the central role of FLOWERING LOCUS $C$ (FLC). Proc Natl Acad Sci USA 97:3753-3758

Simpson GG, Dean C (2002) Arabidopsis, the Rosetta stone of flowering time? Science 296:285-289

Simpson GG, Gendall AR, Dean C (1999) When to switch to flowering. Annu Rev Cell Dev Biol 15:519-550

Simpson GG, Quesada V, Henderson IR, Dijkwel PP, MacKnight R, Dean C (2004) RNA processing and Arabidopsis flowering time control. Biochem Soc Trans 32:565-566

Smith CS, Weljie AM, Moorhead GB (2003) Molecular properties of the putative nitrogen sensor PII from Arabidopsis thaliana. Plant J 33:353-360

Stitt M (1999) Nitrate regulation of metabolism and growth. Curr Opin Plant Biol 2:178-186

Stitt M, Krapp A (1999) The molecular physiological basis for the interaction between elevated carbon dioxide and nutrients. Plant Cell Environ 22:583-622

Suárez-López P, Wheatley K, Robson F, Onouchi H, Valverde F, Coupland $\mathrm{G}$ (2001) CONSTANS mediates between the circadian clock and the control of flowering in Arabidopsis. Nature 410:1116-1120 
Sun TP, Goodman HM, Ausubel FM (1992) Cloning the Arabidopsis GA1 locus by genomic subtraction. Plant Cell 4:119-128

Sung S, Amasino RM (2004) Vernalization in Arabidopsis thaliana is mediated by the PHD finger protein VIN3. Nature 427:159-164

Takei K, Ueda N, Aoki K, Kuromori T, Hirayama T, Shinozaki K, Yamaya T, Sakakibara H (2004) AtIPT3 is a key determinant of nitrate-dependent cytokinin biosynthesis in Arabidopsis. Plant Cell Physiol 45:1053-1062

Tian Q, Chen F, Liu J, Zhang F, Mi G (2008) Inhibition of maize root growth by high nitrate supply is correlated with reduced IAA levels in roots. J Plant Physiol 165:942-951

Valverde F, Mouradov A, Soppe W, Ravenscroft D, Samach A, Coupland G (2004) Photoreceptor regulation of CONSTANS protein in photoperiodic flowering. Science 303:1003-1006

Vanacker H, Sandalio LM, Jiménez A, Palma JM, Corpas FJ, Meseguer V, Gómez M, Sevilla F, Leterrier M, Foyer CH, del Río LA (2006) Roles for redox regulation in leaf senescence of pea plants grown on different sources of nitrogen nutrition. J Exp Bot 57:1735-1745

Vidal EA, Gutiérrez RA (2008) A systems view of nitrogen nutrient and metabolite responses in Arabidopsis. Curr Opin Plant Biol 11:521-529

Vidal EA, Araus V, Lu C, Parry G, Green PJ, Coruzzi GM, Gutiérrez RA (2010) Nitrate-responsive miR393/AFB3 regulatory module controls root system architecture in Arabidopsis thaliana. Proc Natl Acad Sci USA 107:4477-4482

Wada KC, Yamada M, Shiraya T, Takeno K (2010) Salicylic acid and the flowering gene FLOWERING LOCUS $T$ homolog are involved in poor-nutrition stress-induced flowering of Pharbitis nil. J Plant Physiol 167:447-452

Wang R, Guegler K, LaBrie ST, Crawford NM (2000) Genomic analysis of a nutrient response in Arabidopsis reveals diverse expression patterns and novel metabolic and potential regulatory genes that are induced by nitrate. Plant Cell 12:1491-1510

Wang R, Okamoto M, Xing X, Crawford NM (2003) Microarray analysis of the nitrate response in Arabidopsis roots and shoots reveals over 1000 rapidly responding genes new linkages to glucose, trehalose-6-phosphate, iron, and sulfate metabolism. Plant Physiol 132:556-567

Wang R, Tischner R, Gutiérrez RA, Hoffman M, Xing X, Chen M, Coruzzi G, Crawford NM (2004) Genomic analysis of the nitrate response using a nitrate reductase-null mutant of Arabidopsis. Plant Physiol 136:2512-2522

Wigge PA, Kim MC, Jaeger KE, Busch W, Schmid M, Lohmann JU, Weigel D (2005) Integration of spatial and temporal information during floral induction in Arabidopsis. Science 309:10561059

Wilson RN, Heckman JW, Somerville CR (1992) Gibberellin is required for flowering in Arabidopsis thaliana under short days. Plant Physiol 100:403-408

Wiltshire JJ, Cobb AH (1996) A review of the physiology of potato tuber dormancy. Ann Appl Biol 129:553-569

Zhang HM, Forde BG (1998) An Arabidopsis MADS box gene that controls nutrient-induced changes in root architecture. Science 279:407-409

Zhang H, Jennings A, Barlow PW, Forde BG (1999) Dual pathways for regulation of root branching by nitrate. Proc Natl Acad Sci USA 96:6529-6534

Zhang H, Rong H, Pilbeam D (2007) Signalling mechanisms underlying the morphological responses of the root system to nitrogen in Arabidopsis thaliana. J Exp Bot 58:2329-2338 